\section{2. 口腔領域における免疫グロブリンの局在}

\section{○井上 博雅・内山 長司}

(九雨大・日紐)

粘膜下組織には小リンパ組織が散在しているが，この 部位での免㽷グロブリンに関する役割および分泌機序に つてはとんど知られていない，演者らは，てれら免度 グロブリンが全身的なものと異った役割をもつものと考 え，まずIgGに注目し量的，質的、検索在試みた。この ため single radial immunodiffusion (SRID) および enzyme immunoassay（EIA）による定量を試み，ま た自然抗体の有無について調べた。

1. SRIDの娭量線では，少なくとも25〜200 $\mu \mathrm{g} / \mathrm{ml} の$ 簐囲で定量可能であった。タリオスタット在用いる方法 で抽出し, SRID により定量した結果, 新鮮組織 $1 \mathrm{~g}$ 当 り歯肉 0.80 , 口蓋粘膜 1.00 , 下顎口唇粘膜 0.83 , および 頓粘膜0.92mgのIgG を含むこ々が示された。小腸では $1.25 \mathrm{mg}$ と口腔粘膜組織に近い值であった。乾燥重量 $1 \mathrm{~g}$ 当りでは, 各組織とも約 $5 \mathrm{mg}$ 前後であった。

2. EIAの材料として, peroxidase 標準 IgG を $\mathrm{NaIO}_{4}$ により結合させゲルろ過後さらに抗 IgG 血清不 溶化ゲルに吸着させ調製した。EIAにより少なくとも $1 \sim 400 \mu \mathrm{g} / \mathrm{ml}$ まで定量可能であった, 組織抽出希积液 のIgG定量值は異常な值を示し，抽出液中の catalaseが 影響したものと思われる。

3. 口腔常在菌を培養後, 塗捄, 固定した試料に, 正 常ラットの煩粘膜または血清からのIgG を処理し，抗 IgG抗体染色するととにより，両 IgG 画分に自然抗体が 検出された。

\section{3. 人工的骨欠損に対する微小電流の影響について} ○久保田浩三・唐木 良一・山本 博武 (九歯大 $\cdot 2$ 保)

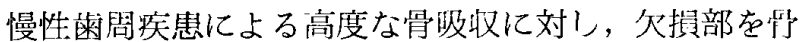
組織で修復する目的で，種々の治療法が研究されてき た。われわれは，新しい試みとして，歯槽骨久損部への 微小電流の応用の可能性について，検䣓を重称ている.

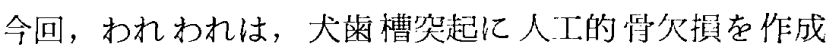

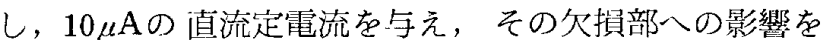
評価した。

実験は，雄雑種成犬の下顎骨を用いた。実験期間は 4 週及び 6 週間とし，各々 3 頭を使用した。骨欠損は下箩
第 2 ・第 3 前臼歯間及び第 3 ・第 4 前目歯間䨑槽頂部に 深さ約 $3 \mathrm{~mm}$ の水平性消欠損を作成した。直径 $0.7 \mathrm{~mm}$ のKirshner 鋼線を，尖端部のみ約 $3 \mathrm{~mm}$ 程度露出し他 をテフロンで絶縁したものを，電極として下顎下緣から 柬槽頂まで，骨髄腔を貫通し刺入した。左側電㮽々のみ 通電し，乙れを通電側とした。右側電極は通電を行わ ず，乙れを control 側とした。実験終了後屠殺し，電 標を中心とした 10枚の非脱灭切片を作製し計测に用い た。仮骨形成量の計測及び，internal remodeling を組 織動態の観点から検討した.

その結果，1）仮骨形成は anode 側において通電によ り抑制され，cathode 側では，通電により促進された。

2) 吸収腔数 (Ar), 類骨圆を伴与县学位数 (os Af), tetracyclineを取り込んだ盈単位〈tc Af ，は共に通電 により control 側に比して高值を䏡し，通䉓により internal remodeling が高められることを示した。

\section{4. 口呼吸が歯列弓に及ぼす影響 第 2 報 口腔内陰圧 について}

○大凉・分山 英次・藤田 邦彦
佐藤 通泰

口呼吸が上顎前突の原因の一つに上げられているが， これは虐の位置や歯列の形態を決定する因子としての口 唇, 煩, 舌等の斿とそれらから生じる口腔内陰压との バランスが，口呼吸によって変化した結果，引き起てさ れるものと考えられる。しかし，乙れに関する実験的証 明は未だ不十分である．先演者らは第40问本学会総会 で，正常呼吸時之口呼吸時の口唇，煩，舌压について報 告した，今回は，いわゆる正常跤合を有する20歳〜25歳 までの男女13名について，安静状態における上靧中切霆 唇側（以後，唇側），口蓋中央部（以後，口蓋側，上顎 小臼歯煩側（以後，煩側）の口腔内陰压を正常呼吸時30 分閶，人為的口呼吸時 30 分間の $2 つ の$ 条件下で測定し た。装置は超小型圧力センサ（共和電業製 PS $2 \mathrm{KA}$

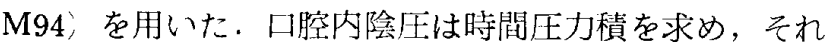
をもとに計算した，結果：1）唇圧は，正常呼吸時㴶均 $-3.89 \pm 0.49 \mathrm{~cm} \mathrm{H}_{2} \mathrm{O}$, 口呼扱時平均 $-1.34 \pm 0.28 \mathrm{~cm}$ $\mathrm{H}_{2} \mathrm{O}$ で正常呼吸時の方が大きくその差は有意であった。 正常呼吸加ら口呼吸への変化（以後, 呼吸様式変化）に 伴い全例, 陰圧が減少し, 平均 $2.55 \pm 0.45 \mathrm{cmH}_{2} \mathrm{O} の$ 減少を正した。 2 门蓋側の陰压は，正常呼吸時平均 $-9,49-1.63 \mathrm{cmH}_{2} \mathrm{O}$, 口烀吸時平均 $-4.72 \pm 1.26 \mathrm{~cm}$ $\mathrm{H}_{2} \mathrm{O}$ で正常呼吸時の方が大きくその差は有意であっ 